\title{
ON THE CONCENTRATION OF PROTEIN IN SAMPLES OF NORMAL URINE MEASURED BY ITS SURFACE ACTIVITY
}

\author{
By R. GUNTON AND A. C. BURTON \\ (From The Department of Medical Research, Faculty of Medicine, University of Western \\ Ontario, London, Canada)
}

(Received for publication February 3, 1947)

\section{INTRODUCTION}

The appearance of albumin in quantity sufficient to give "positive" results by well known "clinical" precipitation tests, has long been regarded as a reliable indication of kidney dysfunction. The reliability, of course, depends on the assumption that in normal physiology, the glomerular "ffilter" is wholly impermeable to protein molecules. Direct evidence of this came from the beautiful experiments of Richards and his co-workers. Walker, et al. (1) found that in some of their samples of capsular fluid in the mammalian kidney the protein was less than $30 \mathrm{mgm}$. per cent, although the smallest degree of mechanical trauma resulted in the appearance of large amounts of protein. The question of resorption of protein in the tubules has been raised, though Bott and Richards found no evidence of this in amphibia (2). Some textbooks state that protein is not a normal constituent of urine (3). Other textbooks are content to state that "normal urine usually contains a trace of albumin too small to be detected by regular tests" (4). Again a "faint trace" by these tests is variously estimated from $30 \mathrm{mgm}$. per cent to as much as $100 \mathrm{mgm}$. per cent of protein ( $5 \mathrm{a}$ and b), and quantitative information as to the amount of protein found in normal urine is hard to find in the literature. Even though there have been discussion and work on the so-called "normal" or "benign" albuminurias ( $6 a$ and $b$ ), quantitative measurements even in this field are lacking.

Bodansky (7) states, without reference, that normal urine contains 2 to $5 \mathrm{mgm}$. of protein per cent; Kolmer and Boerner (8) give figures that indicate an average of $5 \mathrm{mgm}$. per cent, and Everett (5) says that normal urine contains 1 to 6 mgm. per cent. Most references are to the classical work of Mörner (9), who found from 2.2 to $7.8 \mathrm{mgm}$. per cent protein. However, he was more concerned with the chemical nature of the protein and related substances than with a statistical evaluation of the quantity normally present.

The quantitative methods of measurement of protein in urine are capable of measuring much smaller amounts, down to perhaps 5 or $10 \mathrm{mgm}$. per cent but this is only if relatively large samples are available. Thus, they are not suitable for quantitative studies on the time-course of albuminuria, produced experimentally or pathologically.

It is evident that there is a possibility that a given sample of urine might contain protein in amounts too small to be detected by the commonly used methods, yet this amount could be much greater than the amount found in truly "normal" urine. It becomes of importance to establish in a quantitative and statistical manner, what amount of protein is to be expected in a sample of normal urine. The method to be described is an adaptation of one first demonstrated to us by Dr. J. B. Bateman, for measuring the amount of protein in cerebrospinal fluid, and so used by Bazett and Burton (10). It is essentially the method of Gorter and Grendel (11), for serum proteins, simplified for clinical use and applied to urine.

\section{APPARATUS}

The apparatus required is very simple and inexpensive. (See Figure 1.) Surface films are formed on buffer in a plastic tray (of lucite) 36 by 11.5 by $2 \mathrm{~cm}$. over-all, with a well which is accurately $10 \mathrm{~cm}$. wide and $0.5 \mathrm{~cm}$. deep. Black plastic is used for the bottom of the tray, as this greatly facilitates seeing the oil-drops used in the method. Several "barriers" of plastic, $12 \mathrm{~cm}$. long and $1 / 4$ inch square in cross section, are required, and one of these is rigidly fixed at right angles to a long guide piece, carrying a scale which shows the area of the well enclosed between the barrier and the end of the tray. All other apparatus (a 5-ml. burette, pipettes, etc.) is standard in chemical laboratories, except perhaps the platinum wire set in a glass handle. The total cost of apparatus is certainly less than $\$ 10.00$. 


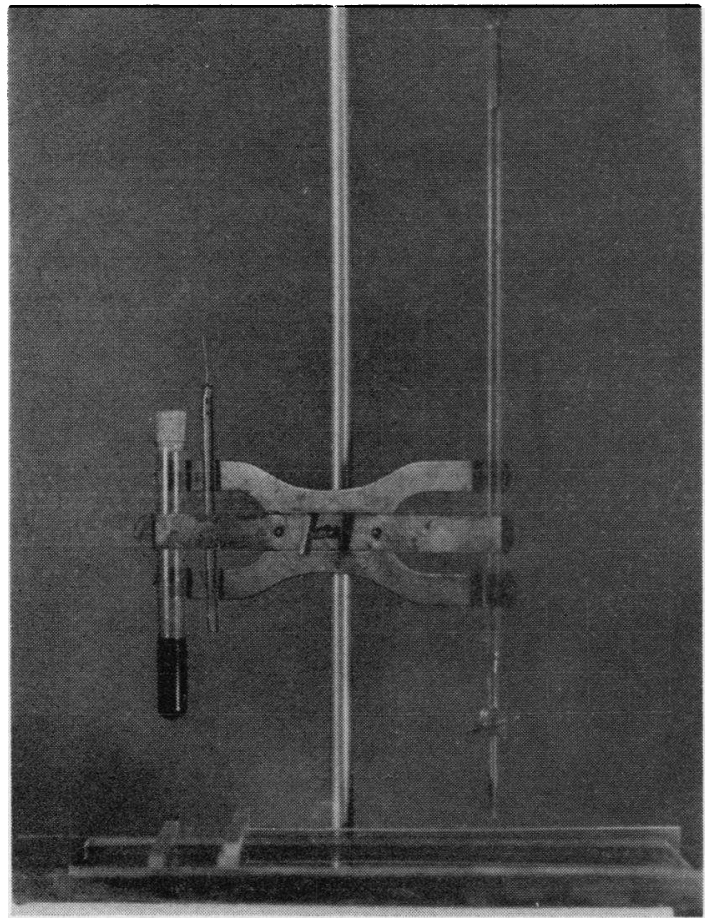

FIG. 1

\section{METHOD}

The method consists of measuring the total surface activity of a sample of urine and then the residual activity after protein has been precipitated. The difference gives the activity due to protein. This divides itself naturally into several successive steps:

\section{(a) Preparation of tray's and barriers}

The tray and barrier must first be cleaned with distilled water and rendered hydrophobic. We have found that paraffin wax is much less satisfactory as a hydrophobic agent than is ferric stearate. This, though difficult to purchase, is very easily made. The following instructions are given by Dr. A. DeLuca who kindly made the ferric stearate we used:

To some hot water $\left(80^{\circ}\right.$ C. $)$ add a quantity of stearic acid. The latter melts forming a layer above the water. Next, add a solution of $\mathrm{FeCl}_{3}$, drop by drop until the water layer is a deep brown. Continue the heating for 15 to 30 minutes with stirring. Let the mixture cool, after which the ferric stearate forms a solid sheet above the liquid. Wash the impure compound by adding it to hot distilled water, and again allowing it to cool. The ferric stearate which reforms on cooling is then broken into small pieces and dropped into a test tube. The latter is placed in a water bath to melt the compound. After cooling the ferric stearate may be removed from the test tube in the form of a solid stick. It may be necessary to pass the test tube momentarily through a flame in order to cause the stick to fall out readily.

All surfaces that will be in contact with the liquids are rubbed with a stick of ferric stearate, then rubbed to a hard polish with paper tissue (Kleenex). This surfacing with stearate should be repeated at frequent intervals, certainly after each day of use of the apparatus.

\section{(b) Buffer used}

A buffer of $\mathrm{pH} 6.4(307 \mathrm{ml}$. of $0.1 \mathrm{M}$ citric acid added to $693 \mathrm{ml}$. of $0.2 \mathrm{M}$ disodium phosphate) has been routinely used. This $\mathrm{pH}$ was chosen as the result of experiments on the surface activity of a given urine sample on buffers of various $\mathrm{pH}$ values. The method is most satisfactory from $\mathrm{pH} 6.0$ to $\mathrm{pH}$ 7.0. The buffer is poured into the tray until it stands well above the edges, the shape of the meniscus indicating the "unwettable" nature of the stearate-treated plastic material.

\section{(c) Removing contamination}

Contamination by surface-active substances either from the tray and buffers or from the air is inevitable. It is minimized by "sweeping" the surface of the buffer with the barriers repeatedly and wiping the barriers clean between each operation with a fresh piece of paper tissue. This "sweeping" was first discovered by Pockels (12). We routinely have swept the tray 3 times before each "blank" or urine determination.

\section{(d) Forming the protein monofilm}

Protein is so active in forming surface films that for the range of concentration of interest in the research, namely from 0 to $80 \mathrm{mgm}$. per cent, the sample of urinc is first diluted in the ratio of 10 to 1 with distilled water. (One ml. urine was added to $9 \mathrm{ml}$. of distilled water.) The diluted sample was then placed in the 5-ml. burette. The stop-cock of the burette should have a minimal amount of stop-cock grease, which is itself surface-active. Unless solutions containing organic solvents are left for long periods of time in the burrette, we have found little trouble from contamination with stop-cock grease. Where there is trouble from this source, it can be avoided altogether by using a dropping-pipette having no stop-cock.

To form the protein film, all that is needed is to allow the diluted urine in the burette to drop slowly (at the rate of 1 drop every 2 or 3 seconds) from a small height into the surface of the buffer (method of Gorter and Grendel $[11,13])$. The top of the burette should be just high enough so that the drops do not touch the surface but fall on to it. Any surface-active substance tends to form a "skin" on the surface of the drops and when these reach the flat surface of liquid in the tray the material spreads rapidly. It will be noted that the drops persist for 2 or $3 \mathrm{sec}$ onds on the top of the buffer before they collapse, whereas drops of pure water from the burette do not show this curious phenomenon. 


\section{(e) Measuring the arca covered by the film}

A barrier pushed along the tray will carry the pro: tein film before it and, after all available space on the surface of the buffer has been occupied by the film, further compression will raise the film pressure as the area decreases. The measurement of area has meaning only if it be made at a definite pressure. To indicate the pressure, the simple device is used of an indicating oil drop). as developed by Blodgett (14), Langmuir and Schaeffer (15). The platinum wire is cleaned by holding in a flame, is then dipped in a test tube of lubricating oil (crank-case oil), and touched briefly to the surface containing the protein film. The oil spreads to a small colorless disc which should not be more than $1 \mathrm{~cm}$. in diameter. As the barrier is pushed up to diminish the area of the film, the area of the oil disc also decreases and its thickness increases, until it is thick enough to show interference colors. These are seen much better in diffuse daylight than in artificial light. The first tint is a straw color, followed with more compression by a first-order blue color, then complicated colors of higher order follow in quick succession as the thickness of oil increases. The oil will always reach a definite thickness, and show a characteristic interference color, at a definite film pressure. We have found that the first-order blue color gives the best critical endpoint. The barrier is therefore pushed steadily along the tray until this color is seen in the oil. Calibration of the particular oil used must be made on a surface balance, of the type now well known, to find the film-pressure corresponding to the endpoint used. In the case of our oil this is 9 dynes per $\mathrm{cm}$. By mixing some "oxidized" (dirty) ${ }^{1}$ oil with clean oil, indicators can be obtained that show critical colors at pressures from 5 to 15 dynes per $\mathrm{cm}$. It will be seen that for the purpose of measuring protein in urine, it is not necessary to know the exact critical pressure of the oil used, except within wide limits, since calibration on standard protein solutions is employed. However, if the areas of film are measured under a different pressure, the calibration curve of the method will, of course, be different from that found in our case.

It will be found that when the endpoint of the critical color is first reached, the color will fade and the area will have to be reduced slightly to produce a permanent indication of endpoint. This is due to viscous properties in the elasticity of the protein film, and the endpoint used in the measurement is that which persists for at least 30 seconds without further movement of the barrier. The area, at this critical point, is then read from the scale.

Since the measurement is made at a film-pressure of 9 dynes per $\mathrm{cm}$., the measured area is considerably less than it would be if made at "zero" pressure, i.e. than the limiting area at zero compression. If the amount of protein dropped on to the surface is too great, the total available area of the tray may be inadequate to accommodate it, and the later drops will not be able to form a monomolecular

1 "Oxidized" vil can be easily produced hy heating clean oil in an open dish for a few minutes.

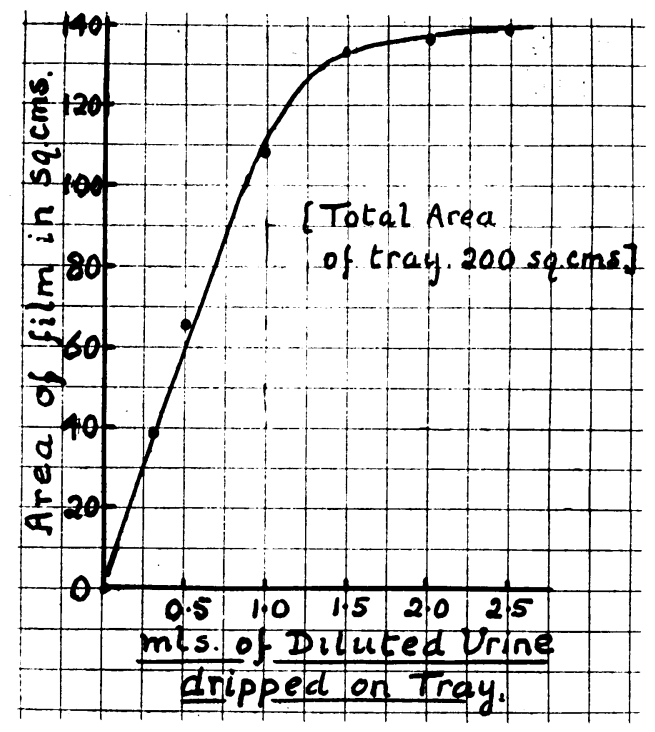

FIG. 2

film. It is important, therefore, to ensure that when the film is formed, the area available is adequate. It was found by repeated tests that if the final area, measured under 9 dynes per $\mathrm{cm}$. pressure, was less than half the total area of the tray, the area was proportional to the volume of diluted urine put on the tray, but if the final area were greater, the measured area was less than would be expected from the amount put on (Figure 2). This indicates that the limiting area (at zero pressure) is about twice that at the pressure of 9 dynes per $\mathrm{cm}$. used in the measurement. A rule was therefore made that if the measured area was greater than half the area of the tray (say with $1 \mathrm{ml}$. of urine), the determination was repeated using a smaller quantity (say $0.6 \mathrm{ml}$. of urine), until the final area was sufficiently small. Alternately, the urine may be further diluted (say to 20 to 1 instead of 10 to 1 ) and the $1 \mathrm{ml}$. used as previously.

\section{(f) Precipitation of the protein}

Several of the well-known precipitation methods were tried before one was found that was satisfactory. Some, such as trichloracetic acid, while precipitating the protein will markedly increase the residual activity of the non-protein surface-active substances in urine, probably by the release of more active groups. Other reagents, such as tungstic acid and lead acetate, produce a copious flocculent precipitate, and the residual surface activity is greatly reduced, presumably by the absorption of all surface-active substances on the precipitate. Finally, it was found that Tsuchiya's 2 reagent was satisfactory.

\footnotetext{
$\because$ Tsuchiya's reagent is : Phosphotunstic acid $\cdots 1.5$ grams Concentrated $\mathrm{HCl}-5.0 \mathrm{ml}$. 95 per cent ethyl alcohol
}

$93.5 \mathrm{ml}$. 
The activity of urine, freed from protein by precipitation by the reagent, was measured, a considerable amount of egg albumin added to increase greatly the measured activity; the added albumin was precipitated again by the reagent, the $\mathrm{pH}$ adjusted to neutrality with ammonia, and the activity finally measured. After correction for the dilution due to the added reagent, the final activity was consistently about the same as at the start. The success of this reagent is probably due to the use of alcohol which produces a compact precipitate of small surface area, and the absorption of surface-active substances on the precipitate is correspondingly low. It will be seen that in most cases, for clinical determinations, the precipitation and second measurement of activity after precipitation may be omitted.

\section{(g) Routine of measurements}

The sequence of measurements on the tray is illustrated by the table below (Table I) which is for a typical sample of normal urine diluted 10 to 1 . It will be seen that "blank determinations" are made between each "test" measurement. In these the tray is "swept" 3 times, but nothing is added from the burette before the area of film is measured. The areas of "blanks" represent the inevitable contamination. The mean of the "blank" determinations is subtracted from the mean of "test" values to give the area due to the substances added from the burette.

TABLE I

Urine sample diluted 10 times

\begin{tabular}{l|c|c|c|c|c}
\hline \multicolumn{3}{c|}{ Before precipitation } & \multicolumn{3}{c}{ After precipitation } \\
\cline { 1 - 5 } $\begin{array}{c}\text { Ml. } \\
\text { added }\end{array}$ & $\begin{array}{c}\text { Cm. on } \\
\text { scale }\end{array}$ & $\begin{array}{c}\text { Corrected } \\
\text { values }\end{array}$ & $\begin{array}{c}\text { Ml. } \\
\text { added }\end{array}$ & $\begin{array}{c}\text { Cm. on } \\
\text { scale }\end{array}$ & $\begin{array}{c}\text { Corrected } \\
\text { values }\end{array}$ \\
\hline 0 & 1.3 & & 0 & 1.4 & \\
1.0 & 9.7 & 8.4 & 1.0 & 2.9 & 1.5 \\
0 & 1.2 & & 0 & 1.5 & 1.7 \\
1.0 & 9.5 & 8.2 & 1.0 & 3.1 & 1.7 \\
0 & 1.4 & & 0 & 1.2 & \\
\hline \multicolumn{2}{c|}{ Mean } & 8.3 & & & $1.6 \mathrm{~cm}$. \\
\hline
\end{tabular}

Area per ml. of urine $=830(8.3 \times$ width of tray $\times$ dil. $)$ $=160 \mathrm{sq} . \mathrm{cm}$.

Area due to protein $=830-160=670$ sq. cm. in $1 \mathrm{ml}$. of original urine.

The whole procedure can easily be completed in 20 minutes.

\section{CALIBRATION OF THE METHOD}

Calibration was made by measurement of the surface area, due to protein, of a number of samples of urine containing increasing amounts of protein, the amount of protein being also measured by the quantitative gravimetric method of Folin and Denis (16). It was felt that in the calibration, urinary protein, rather than any other albumin, should be used. The urine of a patient, which was found, by the gravimetric determination, to contain

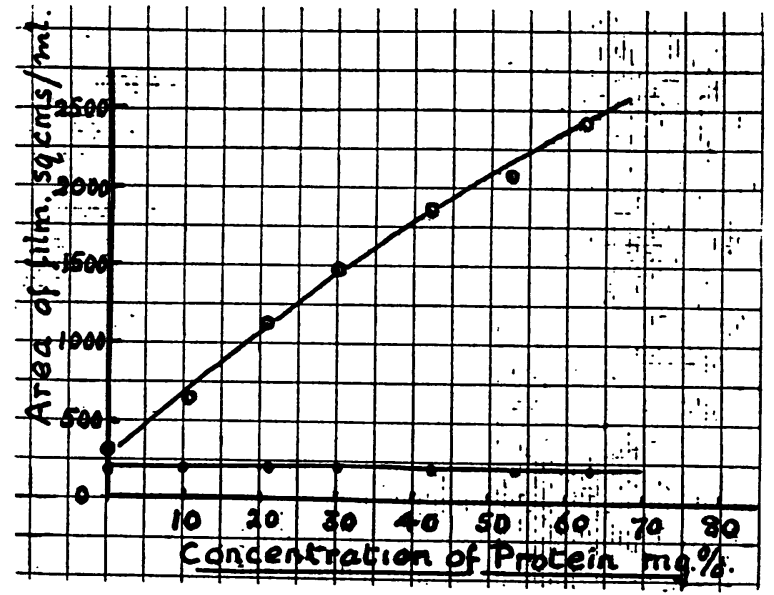

FIG. 3

$240 \mathrm{mgm}$. protein per cent was, therefore, after neutralization, added in different proportions to normal urine which had been rendered free from protein by precipitation. The amount of protein in each of the samples was calculated from the proportions of a mixture of the normal and the protein-containing urines. Results are given in Figure 3, where the open circles represent surface area of film per ml. of original sample before, and the closed circles after, protein precipitation.

\section{RESULTS}

\section{(a) The non-protein or "residual" surface activity in normal urine}

The nature of the "residual" surface-active substances is the subject of a separate research now in progress. In normal urine, the residual activity, found after the protein has been precipitated, is a major part of the total surface activity. The substance or substances responsible for the residual activity are not yet identified, but their activity in normal urine is very constant. In 30 normal subjects, the residual activity from subject to subject, and in the same individual, had a mean from day to day of $206 \mathrm{sq}$. $\mathrm{cm}$. per $\mathrm{ml}$. of urine with a standard deviation of \pm 41 sq. $\mathrm{cm}$. Reference to the calibration curve, Figure 3 , shows that this amount of variability could correspond to a variation in protein of only $\pm 1 \mathrm{mgm}$. per cent. On the other hand, where there is an amount of protein greater than normal, even as little as $20 \mathrm{mgm}$. per cent, the residual activity is a small part of the total activity. Thus for most clinical purposes, the second step of precipitating the protein and remeasuring the surface activity (unless the presence of bile salts 


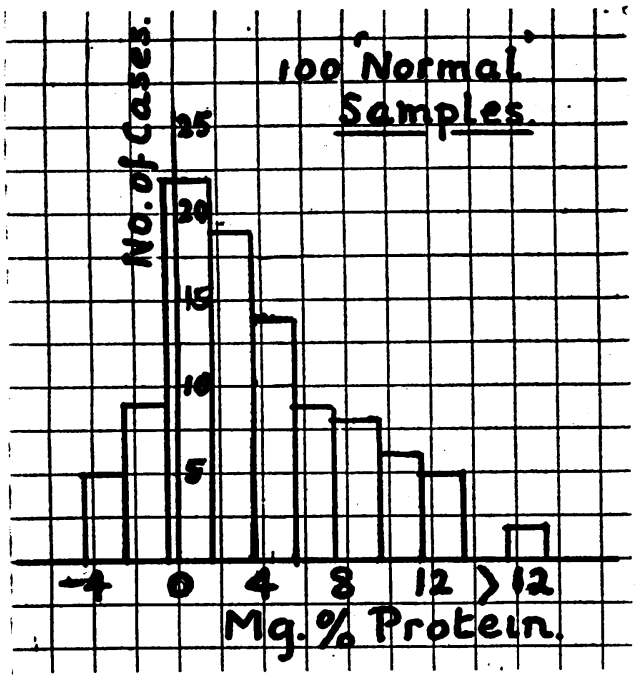

FIG. 4

is suspected), is unnecessary, especially if the total activity indicates a protein concentration within the normal range. To verify this, in 4 cases picked at random, the estimate of protein concentration from the total activity and from Figure 3, was compared with the value from the difference in activity before and after precipitation of protein. In no case did the 2 estimates differ by more than 3 mgm. per cent.

\section{(b) The concentration of protein in samples of normal urine}

Samples of urine were examined by the method described for 100 normal male subjects, most of them students of the Medical School, University of Western Ontario. The criterion of normality was that the blood pressure was within the normal range, with systolic pressure not greater than 140 $\mathrm{mm}$. $\mathrm{Hg}$ and diastolic pressure less than $95 \mathrm{~mm}$. $\mathrm{Hg}$ and that there was no known history of kidney dysfunction.

Results are shown in the histogram Figure 4. The negative values are to be expected because, as in all methods, there is an experimental error; and the true mean value is close to zero. A negative value means that the "residual" surface activity after precipitation was greater, instead of less, than the total activity before precipitation. In the case where the protein concentration is deduced from the total surface activity alone, with- out performing the precipitation, it means that the total activity of that particular sample fell below the "residual" activity on the standard curve.

The mean protein concentration is $3.7 \mathrm{mgm}$. per cent but it should be noted that the distribution is decidedly "skew," and the most frequently occurring concentration (the mode) in normals is between 0 and $2 \mathrm{mgm}$. per cent.

\section{(c) The concentration of protein in urine from patients with higher blood pressure than normal}

The amount of protein in the urine of normals turns out to be so very low that it seemed worthwhile to see if an appreciable number of patients with hypertension, but with no "clinical" evidence of proteinuria, would prove to have concentrations of protein significantly above normal, though below the limit of the normal clinical tests. The group of 50 patients from Victoria and from the Westminster Hospitals, London, Ontario, include 14 who had had some history of heart failure or some degree of decompensation but were free of such conditions at the time of this experiment. Most of the rest were diagnosed as "labile hypertensives," and the clinical tests had shown albumin in amounts described as a "very faint trace" or "insignificant." The group includes some with systolic pressure up to $200 \mathrm{~mm}$. $\mathrm{Hg}$, but diastolic pressures were in most cases less than $120 \mathrm{~mm}$. $\mathrm{Hg}$.

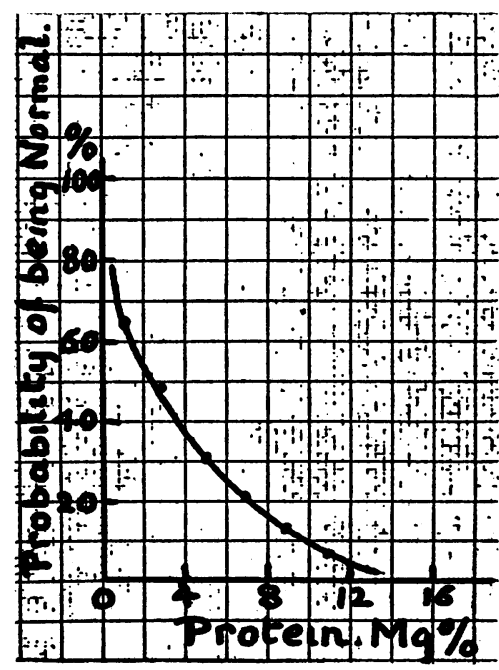

FIG. 5 
Results on this group are shown in Figure 6 in the form of a histogram. Where the protein concentration falls outside the normal range (as judged from Figure 4), the blocks are shaded. In 5 cases where the protein concentration was greater than $80 \mathrm{mgm}$. per cent, these would presumably be noted by the usual clinical tests as having a "trace" of albuminuria. In the 45 other cases, Figure 5 shows that in 15 , or 33 per cent, the protein concentration is significantly greater than the normal.

\section{DISCUSSION}

The curve Figure 3 shows that the area of the protein film is not strictly proportional to the amount of protein present, but there is a slight curvature of the graph. This may be attributed to a "concentration effect," which means that, when protein is more concentrated in the liquid in the burette, the ability to form a film is slightly decreased. This is easily understood, since the more competition there is for the surface of the drops as they are formed, the less completely will the protein be adsorbed on the surface of the drops.

The method of measurement of protein concentration by means of the surface activity is widely adaptable to biological fluids other than urine, such as cerebrospinal fluid, blood serum, or lymph. The initial dilution of these fluids should be such that the concentration of proteins in the fluid dropped in the tray is in the same range as in these measurements, i.e. not greater than $10 \mathrm{mgm}$. per cent. This would require an initial dilution of cerebrospinal fluid some 50 times and of blood serum some 200 times. Since different proteins may differ markedly in their surface activity, calibration should be made with standard solutions of the particular protein concerned.

The specificity of the method in measuring protein, and not other substances, is of course the same as the specificity of the precipitation by Tsuchiya's reagent.

From the results on normal urine, a statistical prediction curve can be constructed as in Figure $\mathbf{5}$ This shows that if a sample of urine is found to contain more than $12 \mathrm{mgm}$. per cent of protein, the chance that this sample is from a "normal" is less than 5 per cent, and for greater amounts, the

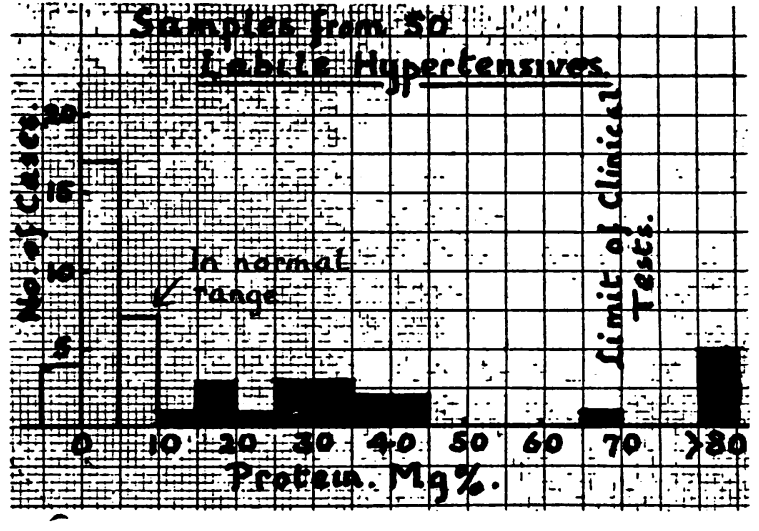

FIG. 6

chance is insignificant. This gives a statistically valid basis for the use of the term "insignificant" in connection with albuminuria, whereas, on the basis of the usual clinical tests, "insignificant" really referred to the appearance of the precipitate in the particular test used and not to the degree of albuminuria.

The amount of protein in normal urine is so small that it would be extremely difficult to establish that what little was present was not extraglomerular in origin, rather than having passed through the glomerular filter. The view that the normal glomerular membrane is "completely" impermeable to protein is not contradicted by these experiments.

The results on the small group of hypertensives are included merely to indicate that a more sensitive method of measurement of urinary protein is of clinical usefulness. The sensitivity of a clinical test should be at least sufficient to give a definite indication with the amount of substance found in normal physiology so that the degree of deviation from the normal can be judged.

\section{SUMMARY AND CONCLUSIONS}

1. Since protein is highly active in forming monomolecular surface films, its concentration in urine can be found by a measurement of the total surface area occupied at a definite surface force, compared with the surface area occupied after protein has been precipitated. For clinical use, it is seldom necessary to take this second step of the precipitation of protein.

2. A simple method, using relatively inexpensive 
apparatus, is described. Less than $1 \mathrm{ml}$. of a sample of urine is required, and the measurement is completed in less than 20 minutes.

3. The method has been used to find the concentration of protein in samples of 100 normal urines. The most frequently found concentration is less than $2 \mathrm{mgm}$. per cent, the mean is $3.7 \mathrm{mgm}$. per cent, and the probability of finding more than $12 \mathrm{mgm}$. per cent in normal samples is less than 5 per cent.

4. When the method is applied to a group of 50 hypertensives, most of them of the labile type, where there was no evidence of albuminuria by the usual clinical tests, amounts of protein significantly greater than normal were found in 33 per cent of these cases.

5. It is concluded that the usual clinical tests for proteinuria applicable on small samples of urine, have a sensitivity which is inadequate to their use. The method employing the surface activity of protein is rapid, easy to perform, requires a very small sample, and is accurate to 2 or $3 \mathrm{mgm}$. per cent. It can be adapted readily to the measurement of the concentration of protein in other biological fluids.

\section{ACKNOWLEDGMENT}

A major part of the technical work was done by $\mathrm{Mr}$. Milton Walsh, and he also contributed a great deal in the development of the method. Thanks are also due to the Medical Staff of the Victoria Hospital and of the Westminster Hospital, London, for their cooperation.

\section{BIBLIOGRAPHY}

1. Walker, A. M., Bott, P. A., Oliver, J., and MacDowell, M. C., The collection and analysis of fluid from single nephrons of the mammalian kidney. Am. J. Physiol., 1941, 134, 580.

2. Bott, P. A., and Richards, A. N., The passage of protein molecules through glomerular membranes. J. Biol. Chem., 1941, 141, 291.
3. Meakins, J. C., The Practice of Medicine. C. V. Mosby Co., St. Louis, 1944, 4th Edition.

4. Levinson, S. A., and MacFate, R. P., Clinical Laboratory Diagnosis. Lea \& Febiger, Philadelphia, 1943, 2nd Edition, p. 385.

5a. Everett, M. R., Medical Biochemistry. Paul B. Hoeber Inc., New York, 1946, 2nd Edition, p. 445.

5b. Kolmer, J. A., Clinical Diagnosis by Laboratory Examinations. D. Appleton-Century Co., New York, 1943, p. 1006.

6a. Starr, I. Jr., The production of albuminuria by renal vasoconstriction in animals and in man. J. Exp. Med., 1926, 43, 31.

6b. Peters, J. P., and Van Slyke, D. D., Quantitative Clinical Chemistry. Williams \& Wilkins Co., Baltimore, 1931, Vol. 1, p. 702.

7. Bodansky, M., Introduction to Physiological Chemistry, Wiley and Sons Inc. New York, 1938, 4th Edition.

8. Kolmer, J. A., and Boerner, F., Approved Laboratory Technique. D. Appleton-Century Co., New York, 1945, 4th Edition, p. 119.

9. Mörner, K. A. J., Untersuchen über die Proteinstuffe und die eiweissfällenden Substanzen der normalen Menschenharns. Skand. Arch. f. Physiol., 1895, 6, 332.

10. Bazett, H. C., and Burton, A. C., Report on the effect of nitrogen liberation on cerebrospinal fluid. Minutes of 4 th Meeting of the Associate Committee on Aviation Medical Research, National Research Council of Canada, Appendix T., June 6, 1941.

11. Gorter, E., and Grendel, F., Die Eiweissausbreitung als Methode zur Bestimmung von Serumalbumin und Serumglobulin. Biochem. Ztschr., 1928, 201, 301.

12. Pockels, A., Nature, 1891, 43, 437.

13. Adam, N. K., The Physics and Chemistry of Surfaces. Oxford University Press, London, 1941, 3rd Edition, p. 87.

14. Blodgett, K. B., Interference colors in oil films on water. J. Optic. Soc. America, 1934, 24, 313.

15. Langmuir, T., and Schaeffer, V. J., Properties and structure of protein monolayers. Chem. Rev., 1939, 24, 181.

16. Folin, O., and Denis, W., The quantitative determination of albumin in urine. J. Biol. Chem., 1914, 18, 273. 